\title{
HYDROGEOLOGY OF GYPSUM FORMATIONS IN IRAN
}

\author{
Ezzat Raeisi*, Mohammad Zare, and Jalal A. Aghdam \\ Department of Earth Sciences, College of Sciences, Shiraz University, 71454, Shiraz, Iran
}

\begin{abstract}
The gypsum formations in Iran are mainly Upper Red (URF), Gachsaran (GF), and Sachun. The GF is divided into salt (SGF) and its non-salt equivalents (NSGF). The conductivity of the spring's water in Sachun, URF and NSGF is below $3500 \mu \mathrm{S} \mathrm{cm}^{-1}$, but the conductivity of the SGF varies from 2400 to $400,000 \mu \mathrm{S} \mathrm{cm}^{-1}$. Three different sites, Tangsorkh (NSGF), Ambal and Salbiz (SGF), were selected for further studies. The Tangsorkh area is composed of alternating units of marlstone and gypsum. The hydraulic connections between these units are broken by the marls and no sub-aquifer is developed in the gypsum units due to their small catchment area and lack of karst development. The Ambal area, adjacent to the large Karun River, consists of units of marl, anhydrite, and halite. Sinkholes cover all parts of the area. Contact of Karun River with the Amble ridge causes the chemistry of the river to evolve from bicarbonate type to chloride type. The presence of the Karun River inside this ridge formed a network of karstic conduits and sinkholes, which causes the marly layers to collapse such that the Ambal area cannot be considered to have several independent subaquifers. The Salbiz site is composed of alternating units of marl-marlstone and gypsum without any sinkholes or exposed salt layers. It consists of independent sub-aquifers with general flow directions parallel to the strike. The study indicates that the GF is mainly composed of small independent sub-aquifers due to its alternative marl or marlstone layers, resulting water flows parallel to the strike, except in the SGF under specific conditions.
\end{abstract}

\section{INTRODUCTION}

Surface outcrops of gypsiferous strata appear quite limited on the global scale. This apparent scarcity can be explained by the relatively low resistance of gypsum to denudation, rather than an actual limited occurrence of sulfate rocks, therefore, the extent of sulfate rocks is greater at depth (Klimchouk et al., 1996). Ford and Williams (1989) estimated that gypsum/anhydrite or halite deposits underlie $25 \%$ of the continental surface (approximately 60 million $\mathrm{km}^{2}$ ), while Maximovich (1962), in Klimchouk et al. (1996), calculated that the area of the continents underlain by gypsum/anhydrite alone is about 7 million $\mathrm{km}^{2}$. It is estimated that gypsum/anhydrite deposits underlie 35 to $40 \%$ of the United States' land area (Johnson, 1996), and they outcrop on 7\% of Spain's land area (Gutierrez et al., 2008) and about $80,000 \mathrm{~km}^{2}$ of Canada's land area (Ford, 1997).

As gypsum is susceptible to rapid dissolution wherever there is active circulation of groundwater that is undersaturated with respect to calcium sulfate, substantial underground voids and cave systems may develop (Johnson, 2003). Gypsum dissolution is one of the most common processes in deteriorating the water quality of aquifers. Water in gypsum karst terrains commonly contains over $1000 \mathrm{mg}^{-1}$ of sulfates, which makes them unsuitable for use as domestic water supply. Much higher concentrations of solutes are not uncommon where gypsum karstification is accompanied by dissolution of the various other salts that are associated with evaporitic sedimentary formations (Klimchouk and Andrejchuk, 1996).
Gypsum formations also outcrop in Iran, especially in the south and southwest of the country. In most of these parts, the gypsum layers are in direct contact with carbonate karstic aquifers or alluvium, deteriorating the good water quality of the adjacent aquifers. Studies on the hydrogeology of gypsum formations in Iran are limited, in spite of the great impact that it has on groundwater quality. Among the gypsum formations, the Gachsaran, with alternative layers of marls, gypsum, and halite, has the highest outcrop in southern Iran (Ashjari and Raeisi, 2006).

This study is focused on preparing a distribution map of gypsum formations in Iran, determining the lithological and hydrochemical characteristic of these formations, and presenting conceptual hydrogeological models in the three Gachsaran Formation aquifers in southern Iran.

\section{Methods}

Two distribution maps of gypsum formations in Iran were prepared based on available scientific information on the stratigraphy and geology of Iran (Stocklin and Setudehnia, 1977; Aghanabati, 2006; Darvishzadeh, 2003; Khosro Tehrani, 1987; Motiei, 1993); on 1:1,000,000, $1: 250,000$, and $1: 100,000$ geological maps from the Geological Survey and Mineral Exploration of Iran dated 1972, 1975, and 2001 or the Iranian Oil Operating Company dated 1965, 1967, 1975, 1976, and 1977; and

*Corresponding Author, e_raeisi@yahoo.com 
on air photos. Some of the hydrochemistry data for this research were obtained from the Karst Research Center of Iran and unpublished M.Sc. thesis in the Geosciences Department of Shiraz University (Rahimi, 2006; Bagheri, 2007). The temperature, electrical conductivity, $\mathrm{pH}$, and discharge of typical springs emerging from gypsum formations were measured in the field during sampling. In the laboratory, calcium and magnesium were measured by titration with EDTA, with Murexide and Erichrom Black-T as indicators. Sodium and potassium concentrations were determined by flame photometery. Sulfate and chloride were measured by the Mohr and turbidity methods, respectively. Bicarbonate was determined by titration with $\mathrm{HCl}$ with methyl orange as indicator. The accuracy of the analyses was estimated from the ion balance. The uncertainty was less than $5 \%$ in all the samples.

\section{Geology and Stratigraphy of GYPSUM FORMATIONS IN IRAN}

The Zagros basin is made of 7 to $14 \mathrm{~km}$ thick sediments over a region along the edge of the Arabian plate. The Zagros region has evolved through different tectonic settings. The stratigraphic column of the Zagros basin contains evaporites. The Hormuz salt (Precambrian) is located at the base of the sedimentary column, and the Gachsaran Formation (GF, Miocene) is composed of widespread evaporate units (Bahroudi and Koyi, 2004). The GF was deposited under the following conditions: evaporation exceeding the supply of seawater, arid climates, and nearly isolated salt basins. The GF was a syntectonic sediment deposited in the northwest-trending synclinal troughs during active folding that divided the Zagros foreland basin into sub-basins with poor water circulation (Berbrian and King, 1981; Hessami et al., 2001). In the salt sub-basins, the two processes of dissolution of extruding Hormuz salts and evaporation were responsible for the deposition of Gachsaran salt. Chemostratigraphic analysis reveals that arid conditions and cycles of transgression-regression of the sea contributed to the formation of the evaporite sequences of the GF in the coastal Sabkha lagoon basin that was partly closed from the open sea by a shallow barrier (Bahadori et al., 2011).

Four main gypsum formations, namely Hith Anhydrite (Late Jurassic), Sachun (late Maestrichtian to early Eocene), Gachsaran (early Miocene) and Upper Red (Miocene-Pliocene) outcrop in Iran (Fig. 1). The total outcrop of the gypsum formations is about $80,000 \mathrm{~km}^{2}, 5 \%$ of Iran's land area. The characteristics of these formations are presented in Table 1 .

The Hith Anhydrite (Late Jurassic) outcrops in southcentral Iran near the Persian Gulf; its area is too small to show on Figure 1. Its thickness is about $91 \mathrm{~m}$ based on the type locality in Kuh-e Asaluyeh. It consists of massive anhydrite-gypsum with interbedded dolomites. The outcrop

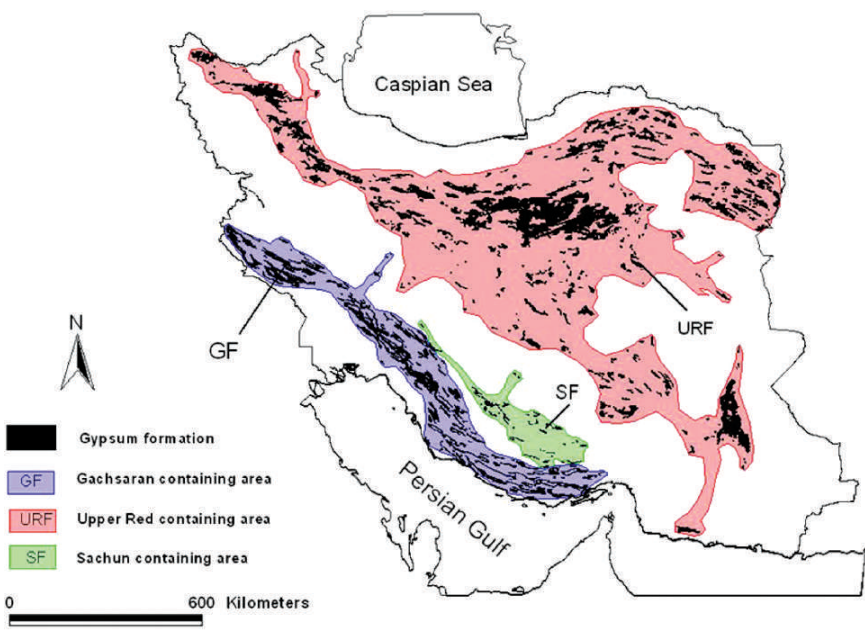

Figure 1. Areas containing outcrops (black) of the main gypsum formations in Iran. The Hith Anhydrite area is too small to show at this scale.

of this formation is only $0.2 \%$ of the total gypsum outcrop in Iran. The Hith Anhydrite is sandwiched between the limestones and dolomites of the Surmeh Formation and the limestones of the Fahliyan Formation. No hydrogeological information is available.

The Sachun Formation (late Paleocene-Eocene) is present only in south-central Iran. The outcrop of this formation is only $1.3 \%$ of the total gypsum outcrop in Iran. The type section was measured at Kuh-e Sachun, about $5 \mathrm{~km}$ north of the village of Sachun. The thickness at the type locality is $1414 \mathrm{~m}$. The bottom 387 meters consists of marl, marlstone, and limestone. These are followed by $91.4 \mathrm{~m}$ of gypsum and dolomite, which are overlain by $112.8 \mathrm{~m}$ of marlstone and dolomite. The succession is continued with $82.3 \mathrm{~m}$ of gypsum with bands of dolomite. Following this are $335.2 \mathrm{~m}$ of chalky marlstone, dolomite, and limestone. The upper $405.4 \mathrm{~m}$ are composed of massive gypsum, marl, and ribs of dolomite (Stocklin and Setudehnia, 1977).

The Upper Red Formation (Miocene-Pliocene) outcrops in the north, center, and east of Iran, composing $73.2 \%$ of the total gypsum outcrop in Iran. No type sections have been specified for this formation. However, the name was first applied to the extensive exposures in the hills of the Qom plain, and it is here that the most detailed studies of the formation have been carried out in both surface and borehole sections by the geological staff of the Iran Oil Company (Mostofi and Frei, 1959). Thus, this area can be regarded as the general type area. The evaporate lower subunit consists of 300 to $500 \mathrm{~m}$ of salt, anhydrite, pebble layers, bituminous paper shales, and dark-red saline plastic clays. The upper subunit has a thickness of 4000 to $5000 \mathrm{~m}$, consisting of gypsiferous marl and sandstone in the lower part and marl and sandstone in the upper part (Stocklin and Setudehnia, 1977). 
Table 1. Area and percent of gypsum formations in Iran.

\begin{tabular}{|c|c|c|c|c|c|}
\hline $\begin{array}{l}\text { Gypsum } \\
\text { Formation }\end{array}$ & $\begin{array}{l}\text { Geological } \\
\text { Time }\end{array}$ & $\begin{array}{l}\text { Percentage } \\
\text { of Iran Area }\end{array}$ & $\begin{array}{l}\text { Percentage of } \\
\text { Gypsum Area }\end{array}$ & $\begin{array}{l}\text { Location } \\
\text { in Iran }\end{array}$ & Lithology \\
\hline Upper Red & Tertiary & 3.63 & 73.2 & $\begin{array}{l}\text { North - } \\
\text { Center - East }\end{array}$ & $\begin{array}{l}\text { marl, gypsiferous marl, } \\
\text { sandstone }\end{array}$ \\
\hline Gachsaran & Tertiary & 1.25 & 25.3 & $\begin{array}{l}\text { South west - } \\
\text { Central South }\end{array}$ & $\begin{array}{l}\text { anhydrite, salt, marl, } \\
\text { limestone, argillaceous } \\
\text { limestone }\end{array}$ \\
\hline Hith Anhydrite & $\begin{array}{l}\text { Jurassic - } \\
\quad \text { Cretaceous }\end{array}$ & 0.005 & 0.2 & Central South & anhydrite \\
\hline Sachun & Tertiary & 0.07 & 1.3 & Central South & $\begin{array}{l}\text { marl, marlstone, limestone, } \\
\text { gypsum, dolomite }\end{array}$ \\
\hline
\end{tabular}

A more detailed distribution map of the Gachsaran Formation is presented in Figure 2. The GF outcrops in southwest and south-central Iran with a total exposure of $20,400 \mathrm{~km}^{2}$, making up $25.3 \%$ of the total gypsum outcrop in the country. The Zagros foreland basin is divided into sub-basins where Gachsaran salt and its non-salt equivalents were deposited (Bahroudi and Koyi, 2004). The Salt Gachsaran Formation (SGF) outcrops in a region from the Kazerun-Qatar faults to Dehloran City. The Non-Salt Gachsaran Formation (NSGF) is classified into Three Members and undifferentiated. The Three Members Gachsaran Formation (TMGF) outcrops between Bandar-e-Abbas and Firuzabad, while undifferentiated NSGF outcrops in two different regions, from Firuzabad to the Kazerun-Qatar fault and north of Dehloran City (Fig. 2). The thickness of the GF usually varies over short distances (Dunnington, 1968; O’Brien, 1957; Stöcklin, 1968), typically from several hundred up to 2000 meters (Edgell, 1996; James and Wynd, 1965; Murris, 1980; Stöcklin, 1968; Bahroudi and Koyi, 2004). Although the GF is generally considered as lower Miocene in age (James and Wynd, 1965), stratigraphic correlations between wells on Qeshm

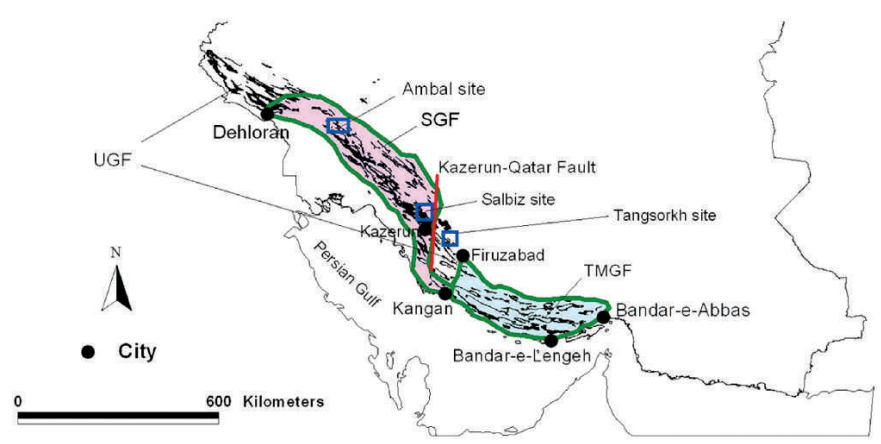

Figure 2. Distribution map of the Gachsaran Formation and its parts in Iran. SGF is the salt Gachsaran Formation, and the non-salt Gachsaran Formation (NSGF in the text) is divided into the three member GF (TMGF; Chehel, Champeh, and Mol Members) and the undifferentiated GF (UGF).
Island in the extreme southeast of the basin reveals that its base is Oligocene or even older (Eocene). The base of the Fars group is diachoronous along the foreland basin and becomes younger with evaporite increases northwestward (Fig. 2) (Gill and Ala, 1972; Motiei, 1993; Bahroudi and Koyi, 2004).

The SGF, in the center of which lie the present oilfields, is mainly located in the southwest of Iran. Stocklin and Setudehnia (1977) divided the GF of the salt basin into seven members based on a type section from a well in the Gachsaran Oilfield. James and Wynd (1965) described the members of SGF in ascending order is as follows: Member 1 consists of $39.6 \mathrm{~m}$ of interbedded anhydrite and limestone associated with shale. It is important as a sealing unit over the Asmari Formation oil reservoirs. Member 2, with a thickness of $115 \mathrm{~m}$, is mainly composed of salt, with some anhydrite and thin limestone intercalations. The thickness of Member 3 is $229 \mathrm{~m}$. The lower half of this member consists of thick anhydrite with subordinate salt, and the upper half is composed of interbedded anhydrite, thinbedded limestone, and marl. Member 4 is composed of $848 \mathrm{~m}$ of thick salt beds associated with grey marl, limestone, or anhydrite. Member 5 consists of $324 \mathrm{~m}$ of marl alternating with anhydrite. Member 6 is divided into three parts. The lower part $(103 \mathrm{~m})$ consists of alternating anhydrite, red marl, and limestone. The middle part (121 m) consists of salt and anhydrite, and the upper part $(61 \mathrm{~m})$ is composed of anhydrite with marl alternations. Member 7, with a thickness of $139 \mathrm{~m}$, is overlain conformably by the Mishan Formation and consists of alternating anhydrite, marl, and argillaceous limestone.

Although exposures of Gachsaran rock salt are rare, it is known from wells and quarries in the south of Masjed Suleyman in the Dezful embayment (Dunnington, 1968; Gill and Ala, 1972; Kashfi, 1980; Motiei, 1993; Bahroudi and Koyi, 2004).

The NSGF is divided into undifferentiated GF and the three early Miocene Chehel, Champeh and Mol Members (James and Wynd, 1965). The lowest, Chehel Member, with a thickness of $296 \mathrm{~m}$, predominantly consists of anhydrite or gypsum. Thin interbeds of limestone and 


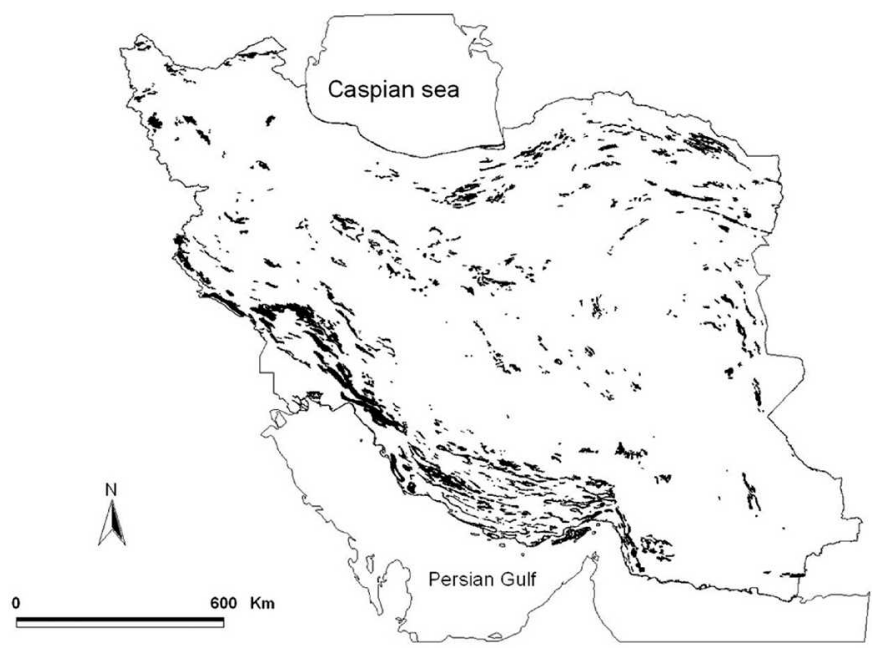

Figure 3. Distribution map of outcrops of additional gypsiferous formations, with minor beds or veins of gypsum, not shown in Figure 1.

marls are common in this unit. The Champeh Member, with a thickness of $110 \mathrm{~m}$ at the type locality, is the middle member of the GF. This member consists of chalkygypsiferous limestones or dolomites, gypsiferous marl, and nodular to massive gypsum. The Mol Member, with a thickness of $52 \mathrm{~m}$, consists of gypsiferous marls interbedded with thin gypsiferous limestone and gypsum. Two small parts of the GF are undifferentiated in the west and the south-central regions of Iran (Fig. 2) and were determined based on the 1965 1:250,000 geological maps of the Iranian Oil Operating Companies. No type localities were studied for the undifferentiated GF, which is mainly composed of alternating units of marl and gypsum with interbedded thin limestones and sandstones. The small $1200 \mathrm{~km}^{2}$ region of undifferentiated GF in the southcentral of Iran is classified into the upper and lower GF (Oveisi, 2001). The upper GF consists of gypsum rocks, gypsum-bearing limestone, marl, and marly limestone, and the lower one is composed of marly limestone, limestone, marl, interbedded sandstone, and gypsum.

The tectonically incompetent units of the Gachsaran Formation are highly subject to dissolution effects, being characterized by responsiveness to differential pressures and extreme mobility. Because of these characteristics, one seldom finds a complete sequence as described at the type locality (Stocklin and Setudehnia, 1977). It is named Gachsaran in most parts of the outcropped area (Aghanabati, 2006).

Other gypsum occurs as thin layers, veins, or inside the matrix in small parts of several formations and units in Iran, mainly marl, marlstone, sandstone, siltstone, mudstone and conglomerate. These formations and units are named gypsiferous formations, as distinct from the gypsum formations of Figure 1 and Table 1, and outcrop in 3.4\% of the total area of Iran (Fig. 3). The characteristics of these formations and units are presented in Table 2 based on the "Stratigraphic Lexicon of Iran" (Stocklin and Setudehnia, 1977).

\section{Hydrogeology of Gypsum Formations}

There are numerous small springs emerging from gypsum formations with flow rates mostly less than a few liters per second, but in exceptional cases up to $60 \mathrm{~L} \mathrm{~s}^{-1}$ (Table 3). There are 165 measurements available for electrical conductivity and 128 measurements for chloride concentrations of water samples, and 73 samples were analyzed for major ions. No chemical analyses are available for samples from the Sachun and Upper Red Formations. The springs in each formation were classified into four groups based only on the EC as follows: Group A less than $1000 \mu \mathrm{S} \mathrm{cm} \mathrm{cm}^{-1}$, Group B between 1000 and $3500 \mu \mathrm{S} \mathrm{cm}^{-1}$, Group C between 3500 and $10,000 \mu \mathrm{S} \mathrm{cm}^{-1}$, and Group D more than 10,000 $\mu \mathrm{S} \mathrm{cm}^{-1}$ (Table 3).

The conductivity of Sachun Formation water varies between 300 to $1400 \mu \mathrm{S} \mathrm{cm} \mathrm{cm}^{-1}$, and the Upper Red Formation varies from 300 to $14,500 \mu \mathrm{S} \mathrm{cm} \mathrm{cm}^{-1}$. Eightyseven percent of the Sachun Formation water samples are classified into group A and the rest into group B. Most of the water samples of the Upper Red Formations are classified into Groups A and B (94\%) and only 6\% into Groups C and D.

The conductivity of waters from the NSGF varies from 300 to $5000 \mu \mathrm{S} / \mathrm{cm}$. The water samples of NSGF are classified as follows: $20 \%$ in Group A, $76 \%$ in Group B, and $4 \%$ in Group C. In Group A, five samples with EC's less than $750 \mu \mathrm{S} \mathrm{cm}^{-1}$ are bicarbonate water type, and three samples with EC's between 800 and $1000 \mu \mathrm{S} \mathrm{cm}^{-1}$ are sulfate type. Groups B and C are sulfate and chloride water types, respectively. Within each group, the springs show the same distributions of ion concentrations (Figs. 4a, b, c). The low EC and dominantly bicarbonate and sulfate water types are expected because the NSGF has very small amounts of halite. The bicarbonate water mainly emerged from alluvium, probably originating from the Chehel Member or sandstone layers, and the sulfate water emerged from gypsum layers.

The conductivity of water from the SGF varies from about 2000 to $400,000 \mu \mathrm{S} \mathrm{cm}{ }^{-1}$. The SGF has members of only three groups: $46 \%$ Group B, $25 \%$ Group C, and 29\% Group D. Out of the forty-one water samples, thirty-two have been chemically analyzed: the water in Group B being sulfate and bicarbonate, while Groups C and D are chloride water. The springs within each group show similar distributions in ion concentration (Fig. 4 d, e, f, g). The high percentage of chloride water is expected because more than $50 \%$ of SGF thickness is composed of salt.

In spite of the limited number of springs, it can be concluded that the alternating layers of gypsum, marlstone, and halite of the Gachsaran Formation result in numerous small sub-aquifers with small discharges, with spring water 
Table 2. Area and percent of gypsiferous formations (gypsum-veins bearing formations) and units in Iran.

\begin{tabular}{|c|c|c|c|c|c|}
\hline $\begin{array}{l}\text { Gypsiferous } \\
\text { Formation, } \\
\text { F / Unit, U }\end{array}$ & $\begin{array}{l}\text { Geological } \\
\text { Time }\end{array}$ & $\begin{array}{l}\text { Percentage } \\
\text { of Iran } \\
\text { Area }\end{array}$ & $\begin{array}{l}\text { Percentage } \\
\text { of Total } \\
\text { Gypsiferous } \\
\text { Formations } \\
\text { Area }\end{array}$ & Location in Iran & Lithology \\
\hline Aghajari F. & Tertiary & 2.09 & 61.22 & South - Southwest & $\begin{array}{l}\text { sandstone, gypsum-veined, } \\
\text { marl, siltstone }\end{array}$ \\
\hline $\begin{array}{l}\text { E1m, E2m, E3m, } \\
\text { E2mg U. }\end{array}$ & Tertiary & 0.26 & 7.74 & Central - East & $\begin{array}{l}\text { gypsiferous marl, marl, } \\
\text { limestone }\end{array}$ \\
\hline Lower Red F. & Tertiary & 0.16 & 4.83 & Central - Northeast & $\begin{array}{l}\text { silty shale, gypsiferous } \\
\text { marl, sandstone, } \\
\text { gypsum }\end{array}$ \\
\hline M1f, Msc U. & Tertiary & 0.15 & 4.32 & Northwest - Southeast & $\begin{array}{l}\text { sandstone, gypsiferous } \\
\text { mudstone, shale, } \\
\text { mudstone }\end{array}$ \\
\hline Qom F. & Tertiary & 0.13 & 3.85 & Northwest - Central & $\begin{array}{l}\text { limestone, marl, } \\
\text { gypsiferous marl, sandy } \\
\text { marl, sandstone }\end{array}$ \\
\hline Shurijeh F. & Jurassic- & 0.12 & 3.60 & Northeast & $\begin{array}{l}\text { gypsiferous marl, marl, } \\
\text { argillaceous limestone, } \\
\text { sandstone, } \\
\text { conglomerate }\end{array}$ \\
\hline Omrb U. & Tertiary & 0.11 & 3.24 & Northwest - Central & $\begin{array}{l}\text { conglomerate, sandstone, } \\
\text { marl, gypsiferous marl, } \\
\text { gypsum }\end{array}$ \\
\hline K1m, K2Im (U.) & Cretaceous & 0.11 & 3.24 & $\begin{array}{l}\text { Northwest - Central - } \\
\text { East }\end{array}$ & $\begin{array}{l}\text { limestone, argillaceous } \\
\text { limestone, Sandstone, } \\
\text { gypsiferous marl, marl }\end{array}$ \\
\hline Pes, Pem, Pems U. & Tertiary & 0.07 & 2.16 & East - Central & $\begin{array}{l}\text { gypsiferous mudstone, } \\
\text { gypsiferous marl, marl, } \\
\text { sandstone, conglomeratic } \\
\text { sandstone }\end{array}$ \\
\hline Ekgy (U.) & Tertiary & 0.03 & 0.77 & Central - North & gypsum \\
\hline PeEm (U.) & Tertiary & 0.03 & 0.85 & North - East & $\begin{array}{l}\text { gypsiferous marl, } \\
\text { gypsiferous mudstone, } \\
\text { marl }\end{array}$ \\
\hline Dalan F. & Permian & 0.03 & 0.99 & West & $\begin{array}{l}\text { dolomitic limestone, } \\
\text { anhydrite, limestone, } \\
\text { dolomite }\end{array}$ \\
\hline Padeha F. & Devonian & 0.03 & 1.01 & Central - Northeast & $\begin{array}{l}\text { quartz arenite, dolomite, } \\
\text { gypsum }\end{array}$ \\
\hline Sabz, Makran U. & Tertiary & 0.02 & 0.64 & Southeast & $\begin{array}{l}\text { gypsiferous and calcareous } \\
\text { marl, marlstone, } \\
\text { siltstone and sandstone }\end{array}$ \\
\hline Eogy (U.) & Tertiary & 0.02 & 0.70 & North & gypsum (salt plug) \\
\hline Ziarat F. & Tertiary & 0.02 & 0.49 & North & $\begin{array}{l}\text { gypsiferous marl, } \\
\text { limestone }\end{array}$ \\
\hline Baidu F. & Jurassic & 0.01 & 0.36 & Central & $\begin{array}{l}\text { sandstone, siltstone, } \\
\text { limestone, marl, gypsum }\end{array}$ \\
\hline
\end{tabular}




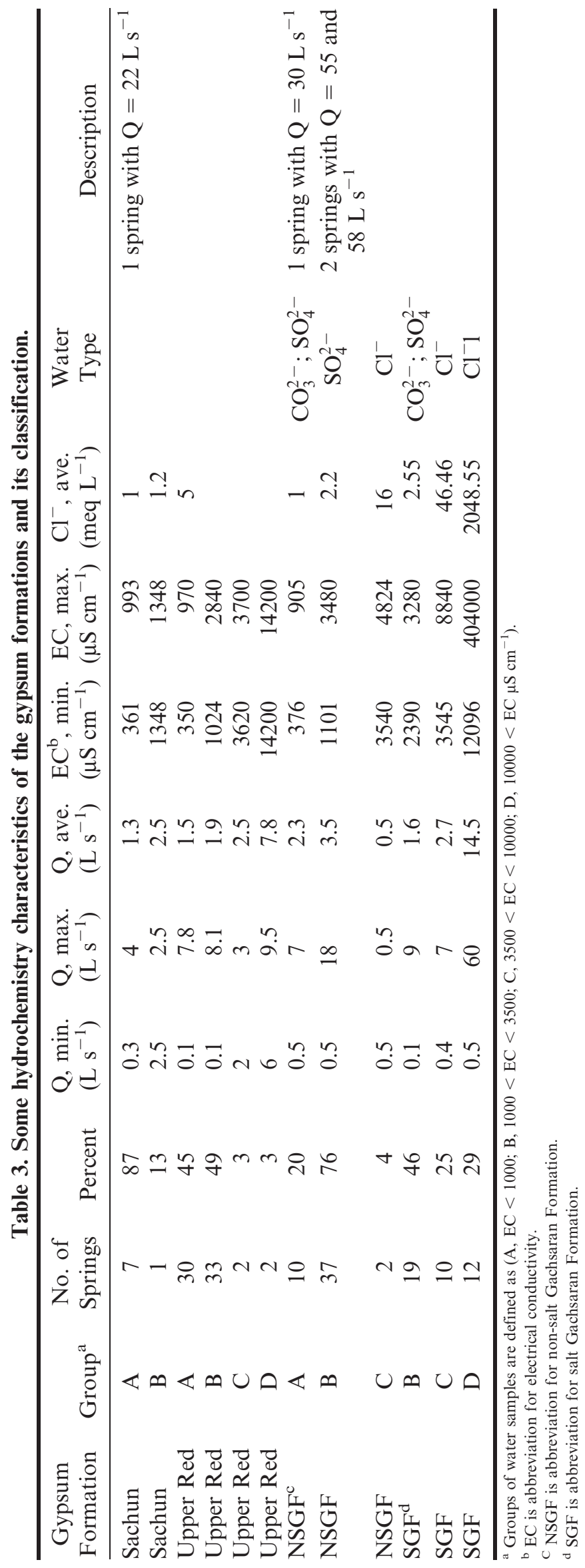

qualities being dependent on the lithology of the flow route. The salinity of the SGF groundwater is higher than the Upper Red and Sachun Formations due to numerous halite units in the SGF.

\section{Hydrogeology of the Gachsaran Formation}

Three sites, namely the Tangsorkh, Ambal, and Salbiz, were selected to study the detailed hydrogeology of the SGF and the NSGF.

\section{TANGSGORKh Site}

The Tangsorkh site is located on the northern flank of the Derak anticline. This area is located in the undifferentiated non-salt GF. A detailed geological cross section perpendicular to the strike of the formation was prepared by detailed field surveying (Aghdam, 2012). The undifferentiated non-salt GF consists of upper and lower parts with thicknesses of 908 and $359 \mathrm{~m}$, respectively (Fig. 5). The GF is composed of twenty-eight, forty-eight, four, and two units of gypsum, marl and marlstone, limestone, and sandstone, respectively. The thickness of most of the gypsum units, which are sandwiched between marls and marlstones, varies from 2.5 to $17.2 \mathrm{~m}$ while they are sandwiched between the marl or marlstone units. No sinkholes or caves are observed in this site. The subaquifers are limited to four limestone, five gypsum, and one gypsum-halite units. Nineteen springs emerge from the subaquifers. Among them, the measured flows varied from 0.3 to $8.4 \mathrm{~L} \mathrm{~s}^{-1}$, with an average of $2 \mathrm{~L} \mathrm{~s}^{-1}$, respectively (Table 4). The main source of flow in most sub-aquifers is Tangsorkh River water that sinks where it crosses limestone and gypsum units. The spring waters of the Tangsorkh area emerging from GF are classified into two Groups, B and C. Group B consist of eighteen springs of sulfate water with electrical conductivities between 1000 and $3500 \mu \mathrm{S} \mathrm{cm}^{-1}$. Of these eighteen springs, a sub-group of consisting of ten springs that emerge from four limestone units and three that emerge from alluvium covering the gypsum units have EC ranging from 1200 to $1800 \mu \mathrm{S} \mathrm{cm}^{-1}$ (subgroup B1). The EC of the five additional springs that emerge from gypsum units varies from 2800 to $3500 \mu \mathrm{S} \mathrm{cm}^{-1}$ (subgroup B2). The unexpected sulfate type of water in the limestone springs is related to recharge by the sulfate Tangsorkh River water and the adjacent marly layers. Group C has only one spring (S12 on Fig. 5) that emerges from a gypsum unit and has an average EC of $4823 \mu \mathrm{S} \mathrm{cm}^{-1}$ and average discharge of $0.5 \mathrm{~L} \mathrm{~s}^{-1}$. The halite in the matrix of this unit changes the type of water to sodium chloride (Table 4).

The diversity in the hydrochemistry of the springs emerging from the limestone or gypsum units indicates that the marly layers prevent hydraulic connections of the adjacent sub-aquifers, leading to flow in the direction of the bedding plane. The dominantly sulfate water in the study area confirms the lack of halite layers in the area. 

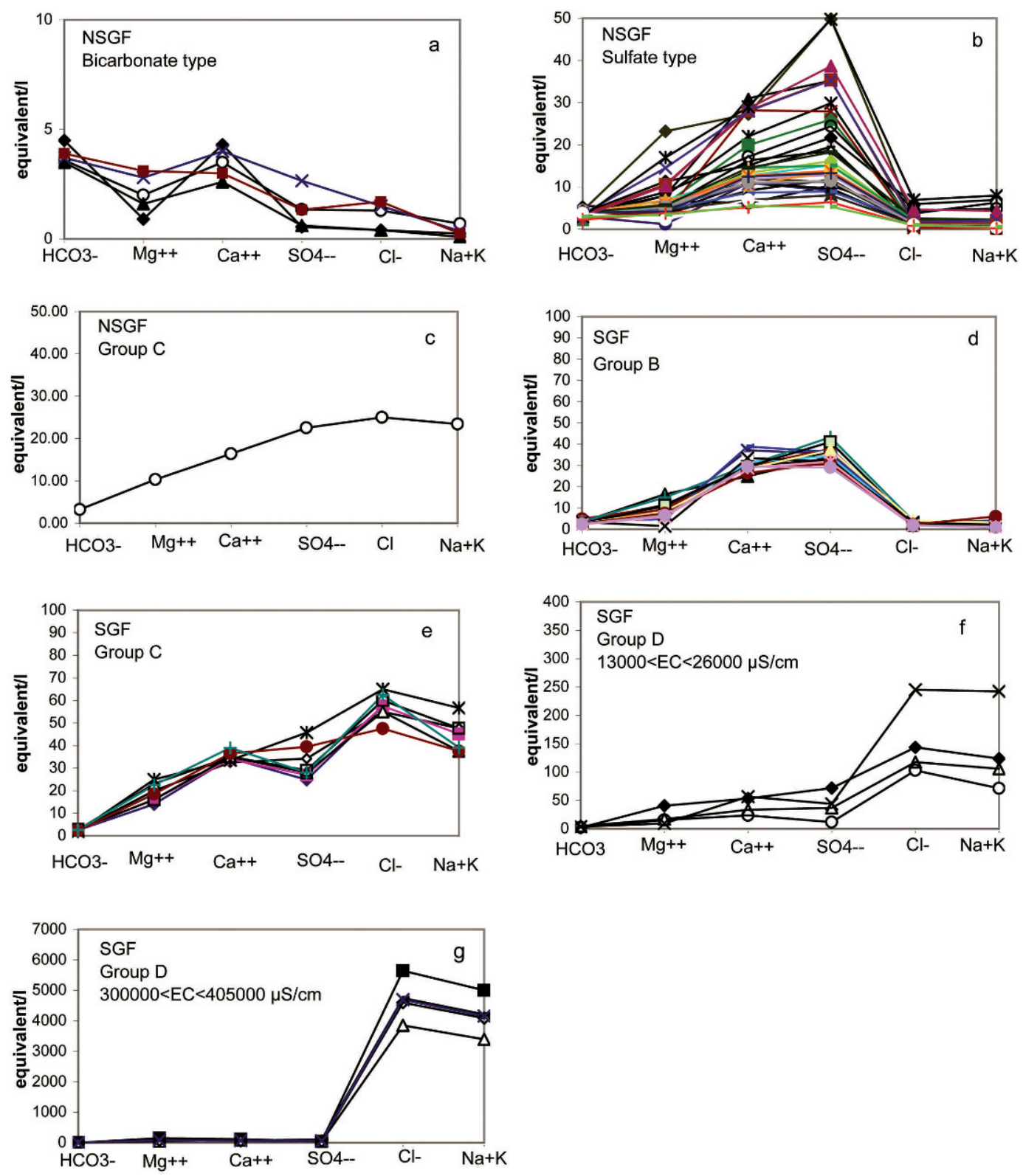

Figure 4. Ion concentrations in spring waters flowing from the non-salt Gachsaran Formation (NSGF) or the salt Gachsaran Formation (SGF), sorted by electrical conductivity groups A-D (see text or note in Table 3). Symbols and colors indentify data from a single spring. (a) NSGF group A bicarbonate water. (b) NSGF group B sulfate water. (c) NSGF group C chloride water. (d) SGF group B bicarbonate/sulfate water. (e) SGF group C chloride water. (f) SFG lower conductivity group D chloride water. (g) SGF higher conductivity group D chloride water.

No springs emerge from twenty-two of the twenty-eight gypsum layers. The main reasons for the lack of springs in those gypsum units are as follows: 1) The Tangsorkh River does not intersect these gypsum units, so precipitation is the only source of recharge. 2) The local base level of the gypsum units are dry drainages intersecting the gypsum units at maximum intervals of $2 \mathrm{~km}$, therefore, the maximum catchment area of the gypsum unit is about $20,000 \mathrm{~m}^{2}$ (maximum length and width of 2000 and $17.2 \mathrm{~m}$ respectively). The average annual flow rate recharging into each gypsum unit is $0.1 \mathrm{~L} \mathrm{~s}^{-1}$ based on annual average precipitation of $500 \mathrm{~mm}$ and recharge coefficient of 0.2 . The drainages are covered by coarse-grained alluvium, draining into the adjacent intersecting gypsum units. The recharge value is extremely low, such that no surface water can be observed on the drainages during the dry period. 3) The small thickness of the gypsum units and the low recharge prevent any sinkhole and conduit development. The flow is diffuse, so the recharge water stays in the top soil and a large fraction of the stored water is evaporated. 

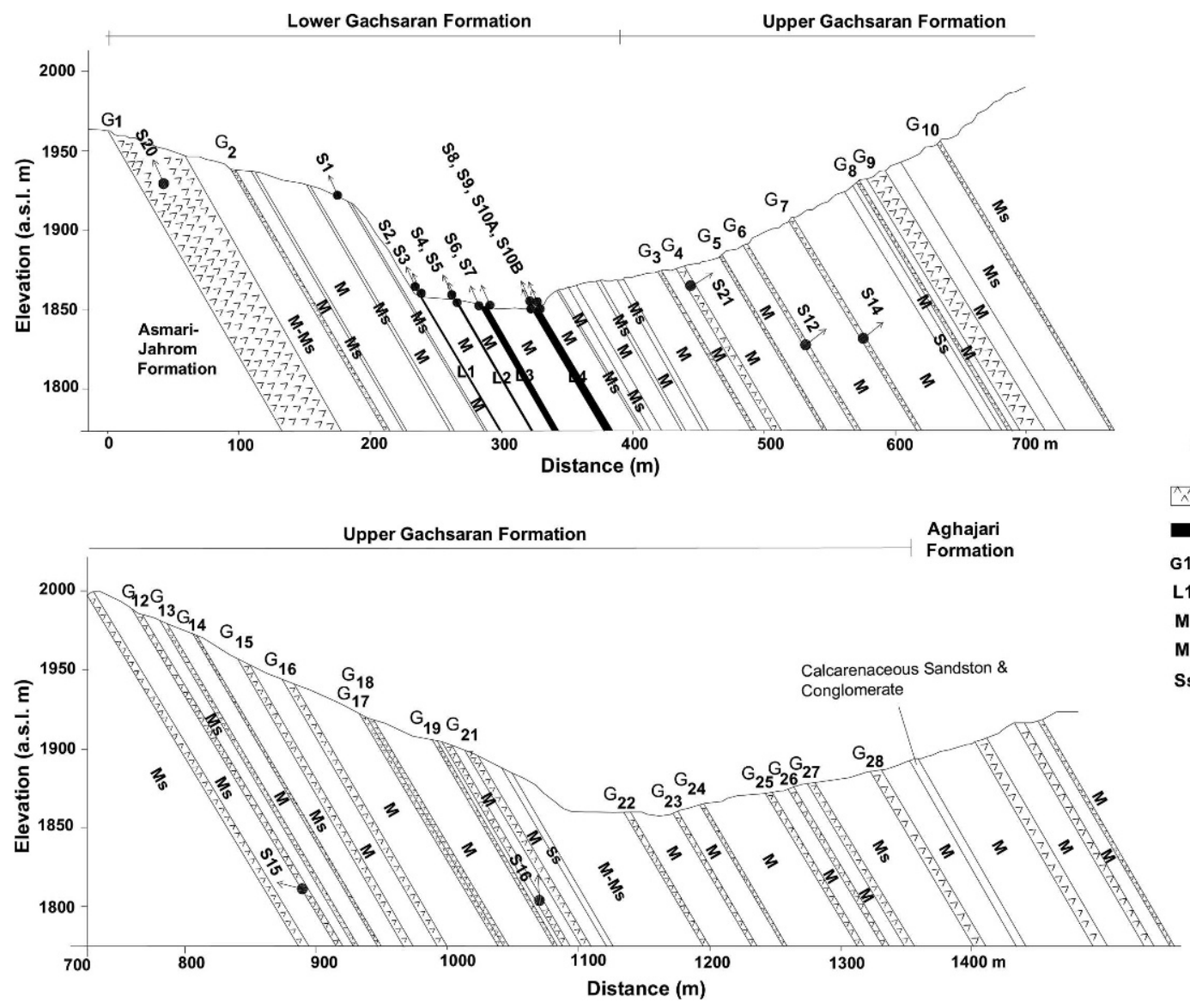

. $\quad$ 1, S2, ...: Spring No. 1, 2, ...

$\triangle \wedge \wedge$ Gypsum layer

Limestone aquifer G1, G2, ...: Gypsum Layer No. 1, 2, ... L1, L2, ...: Limestone Layer No. 1, 2, ... M: Marl Ms: Marlstone Ss: Sandstone

Figure 5. Detailed geological cross section along the Gachsaran Formation at the Tangsorkh site prepared by surveying the outcrop. The horizontal scale is cumulative thickness of the formation, not horizontal distance.

\section{Ambal Site}

This study area in the Zagros Mountains are located in the GSF. The Ambal area is a $17 \mathrm{~km}^{2}$ ridge with a length of $4 \mathrm{~km}$ and an elevation of 100 to $340 \mathrm{~m}$.a.s.l. A detailed geologic cross section, perpendicular to strike of the GF, was prepared based on borehole logs (Mahab Ghodss Consulting Engineers, 2009) (Fig. 6). The thickness of the measured cross section is about 300 meters, with additional undifferentiated GF above and below it (e.g., units of marl, anhydrite, halite, undifferentiated Gachsaran, and mixtures of thin $(<5 \mathrm{~m})$ beds of marl, anhydrite, halite, and occasional gypsum). The salt layers of the GF are not exposed in most parts of Iran, but they are exceptionally outcropped in some parts of this study area. The Ambal ridge area seems to be an active salt structure where tectonic pressures continuously squeeze the salt to the surface, where it is dissolved (Aghdam et al., 2012).

Sinkholes are the dominant karst features in both the gypsum and salt units of the Ambal area. Sinkhole diameters vary from 1 to $130 \mathrm{~m}$. The Karun River is in direct contact with the Gachsaran Formation along $4 \mathrm{~km}$ of the Ambal area. Six springs emerge from the GF a few meters above the Karun River, and numerous springs rise below the water surface. The geological map and location of springs in the studied area are shown in Fig. 7. The springs are classified based on the electrical conductivity of their water into group $\mathrm{D}$, with $\mathrm{EC}$ values ranging within 14,250 to $392,000 \mu \mathrm{S} \mathrm{cm}^{-1}$, all from sodium chloride; total spring discharges are from 0.8 to $7.5 \mathrm{~L} \mathrm{~s}^{-1}$.

The chemistry of Karun River during contact with the GF quickly evolves from bicarbonate type, with a TDS of $\sim 0.4 \mathrm{~g} \mathrm{~L}^{-1}$, to chloride type with a TDS of $\sim 1.5 \mathrm{~g} \mathrm{~L}^{-1}$, mainly due to halite and, to a lesser extent, gypsum. Mass balance and water budget calculations indicate that $5 \%$ of the Karun River's salinity enhancement is from direct precipitation in the Ambal area (Aghdam, 2010). The rest is due to the turbulent flow of river water sinking into the fractures and karstic conduits of the evaporite layers that dissolves the gypsum and salt layers of the GF. The borehole logs showed cavities more than $10 \mathrm{~m}$ in diameter below the river level (Mahab Ghodss Consulting Engineering, 2009). The flow from the Karun River inside the GF developed a network of karstic conduits and sinkholes, collapsing the marly layers between the huge conduits, and thus connecting the layers of halite and gypsum, such that the Ambal area cannot be considered to have several independent subaquifers. 


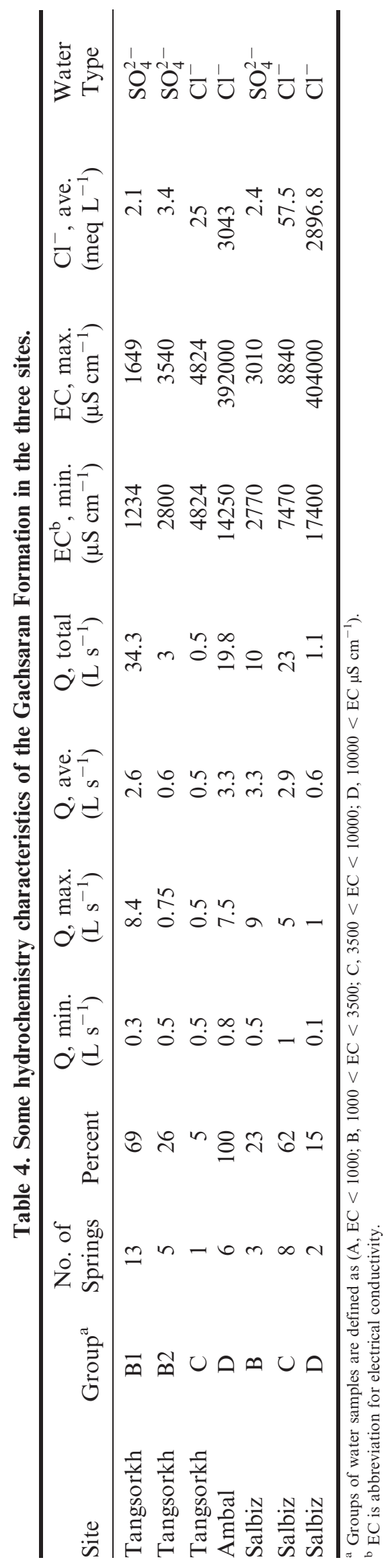

SAlbiz Site

This study area is located in the Salt Gachsaran Formation near the Qatar-Kazerun Fault, $20 \mathrm{~km}$ northwest of Kazerun (Fig. 2). The mean annual potential evaporation is $2641 \mathrm{~mm}$. The study area receives an average of $650 \mathrm{~mm}$ of rainfall per year. No caves or sinkholes are observed in the study area. The only place in the study area with extensive exposure of the Gachsaran layers is the Salbiz Valley. The lithology of the crosssection along this valley is composed of 252 alternating units of marl-marlstone (51\%), gypsum (47\%), and limestone (2\%) (Aghdam, 2012). No salt layers are exposed in this cross section in spite of several springs with chloride type water and elevated electrical conductivity (Table 4 and Fig. 8) and considering the study area is located on seven members of the GF with extensive salt layers in members 2, 3, 4, and 6 . The salt has been leached from the top several meters of the SGF. Therefore, the exposed units are not representative of the full SGF. A full profile must be prepared based on borehole logging.

The water sources along the cross section consist of thirteen springs with the total discharge of $34.1 \mathrm{~L} \mathrm{~s}^{-1}$; in addition water seeps into the Salbiz River in several locations (Fig. 8). It was not possible to measure the discharge of the seeps because most parts of the Salbiz River are inaccessible. The SGF springs are classified into Groups B, C, and D based on their electrical conductivities (Table 4). Group B consists of three springs with EC from 2770 to $3010 \mu \mathrm{S} \mathrm{cm}^{-1}$, sulfate water, and a total discharge of $10 \mathrm{~L} \mathrm{~s}^{-1}$. These springs emerge from gypsum units. Group C is composed of eight springs with EC ranging from 7470 to $8840 \mu \mathrm{S} \mathrm{cm} \mathrm{cm}^{-1}$, chloride water, and a total discharge of $23 \mathrm{~L} \mathrm{~s}^{-1}$. The remaining two springs are classified into Group D, with EC ranging from 17,400 to $404,000 \mu \mathrm{S} \mathrm{cm}^{-1}$, chloride water, and a total discharge of $1.1 \mathrm{~L} \mathrm{~s}^{-1}$.

That ten out of the thirteen springs have chloride water confirms that the SGF here is dominantly salt layers. None of the ten chloride springs emerge directly from halite units due to the leaching of sodium chloride from the surface. The Gachsaran layers are perpendicular to the Salbiz Valley. Water originating in an area far from the river flows deep into the halite units and converges into the river bed, dissolving the deep halite units. Exposed marly layers perpendicular to the Salbiz Valley and small springs with different ranges of electrical conductivity indicate that the SGF is composed of independent sub-aquifers. The Salbiz Valley is the local base of erosion, draining the water from adjacent gypsum and halite layers, preferentially along the bedding planes. The small springs, the limited catchment areas of the sub-aquifers, and the lack of caves and sinkholes imply the absence of conduit flow in the study area.

\section{Comparison of Sites}

The characteristics of the three typical Gachsaran Formation sites are summarized in Table 5. The marly 


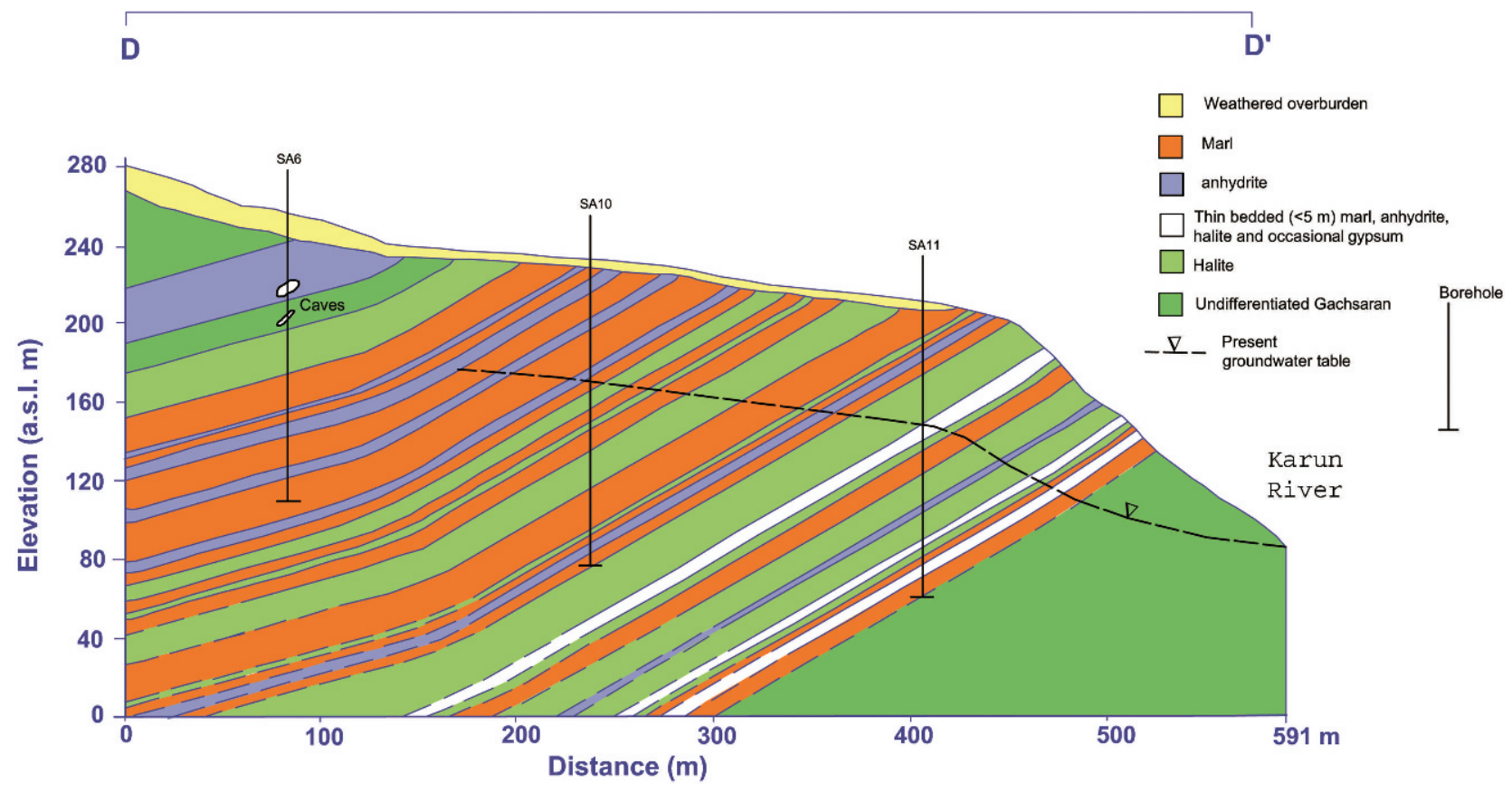

Figure 6. Detailed geological cross section through the Gachsaran Formation at the Ambal site prepared from borehole logs (Mahab Ghodss Consulting Engineers, 2009).

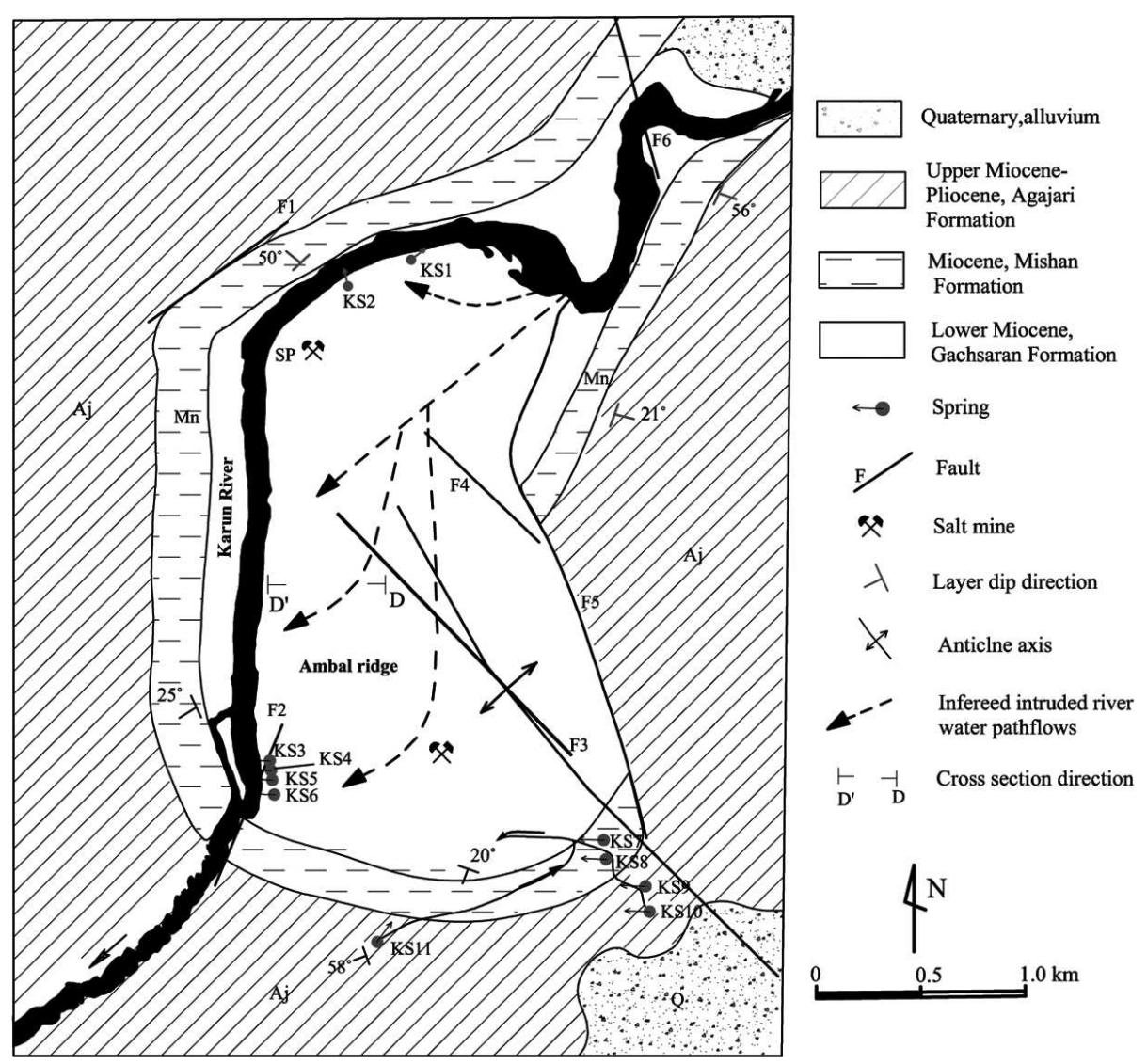

Figure 7. Geology map of the Ambal Ridge study area, including the locations of the sampling points (KS) and inferred flow paths of diverted river water. 

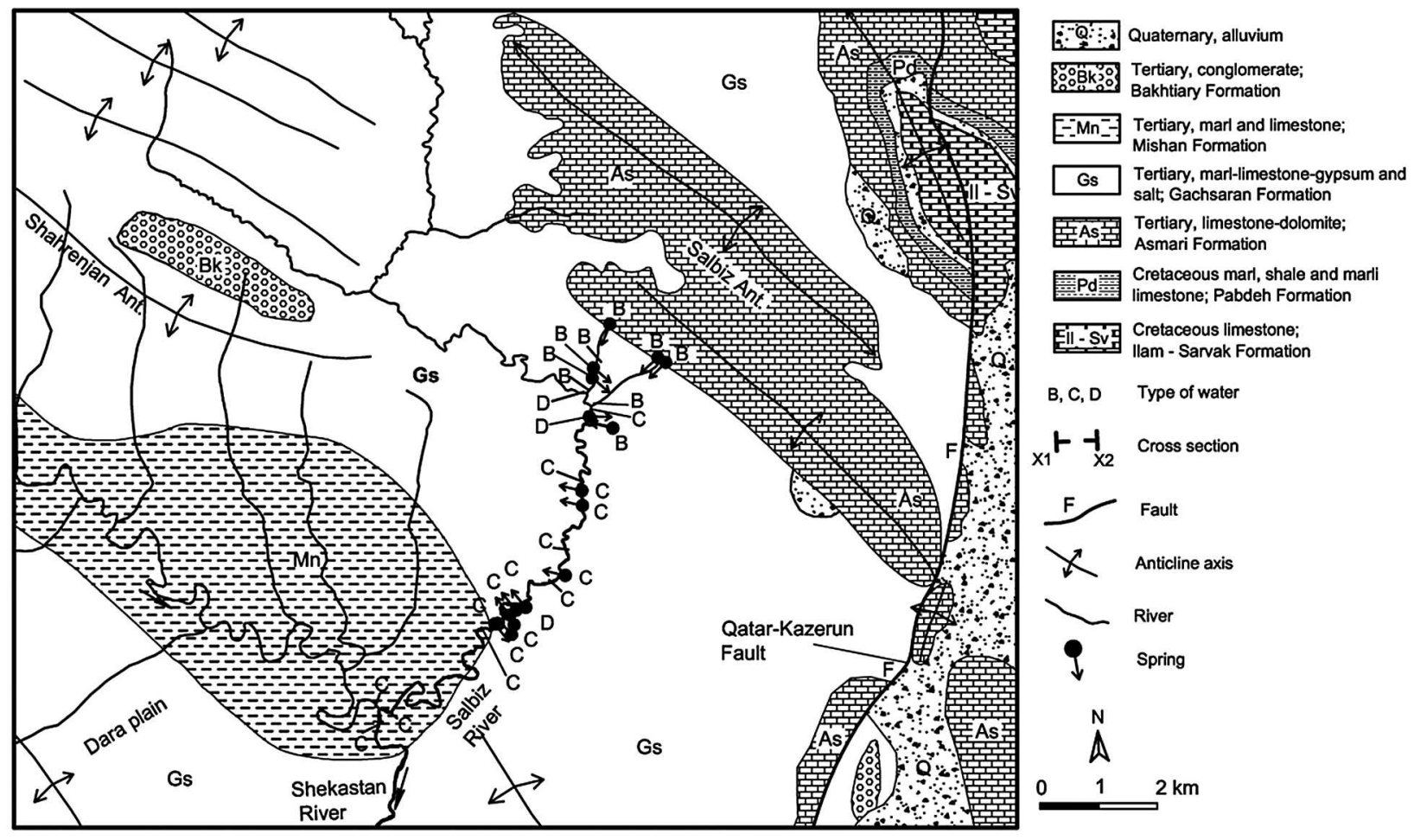

Figure 8. Geology map of the Salbiz site, including the locations of the sampling points labeled by their electrical conductivity group B-D as defined in the text or a note in Table 3. Both springs and surface water sites are shown.

units disconnect the evaporate units in the Tangsorkh and Salbiz sites, resulting in limited catchment areas, flow parallel to the bedding, low-discharge springs, absence of extensive sinkholes and caves, and flow being predominantly diffuse. Tectonic activities exposed salt rocks in the Ambal site, and inflow from the Karun River developed huge conduits beneath the Ambal Ridge, developing extensive sinkholes. As a result, the marly units collapsed, hydraulically connecting the evaporate units. These conditions resulted in a direction of flow toward base level instead of the direction of the bedding planes. The hydrochemistry of these sites is strongly related to the lithology of the groundwater route, such that the springs are sulfate in the Tangsorkh site, with its lithology of marl and gypsum, and sulfate and chloride in the Salbiz site, with a lithology of marl, gypsum, and salt. The type of water is chloride in Ambal, in spite of the alternating gypsum and salt units and groundwater flow through both gypsum and salt units. It is the higher dissolution rate of the salt that controls the hydrochemistry of groundwater in the Ambal site.

Table 5. Comparison of the three sites.

\begin{tabular}{|c|c|c|c|}
\hline Subject & Tangsorkh & Salbiz & Ambal \\
\hline Lithology & marl, gypsum & marl, gypsum, salt & marl, gypsum, salt \\
\hline Salt outcrop & & & extensive outcrop \\
\hline $\begin{array}{l}\text { Hydraulic connection between } \\
\text { evaporites units }\end{array}$ & disconnect & disconnect & connect \\
\hline Karst morphology & no cave, a few sinkholes & no cave, no sinkholes & caves and sinkholes \\
\hline Springs discharge & small & small & $\begin{array}{l}\text { probably large under river } \\
\text { springs }\end{array}$ \\
\hline Karst conduits & no & no & yes \\
\hline Flow type & diffuse & diffuse & conduit \\
\hline Hydrochemistry controlling factor & lithology & lithology & lithology \\
\hline Water type & sulfate & sulfate, chloride & chloride \\
\hline EC range $\left(\mu \mathrm{S} \mathrm{cm}^{-1}\right)$ & mainly bellow 3,500 & bellow 16,000 & 16,000 to 350,000 \\
\hline
\end{tabular}




\section{WATER USE}

Halite dissolution is significantly more detrimental to the quality of spring water than gypsum dissolution. Sulfate type water with electrical conductivity less than $3000 \mu \mathrm{S} \mathrm{cm}^{-1}$ was used for drinking in rural area a few decades ago, but currently, water from carbonate karst springs or wells is piped to rural areas. Sulfate and chloride type water with EC less than $7000 \mu \mathrm{S} \mathrm{cm}^{-1}$ is used for irrigation. The total discharge of the Gachsaran Formation springs is very low, so the contribution of these waters to agricultural products is not significant. Most of the saline and brine springs emerging from the GF join the permanent rivers more or less immediately, and the salinity is diluted to acceptable levels. The worst effects are on the groundwater. Saline and briney water flows from the GF into adjacent karstic Asmari or alluvium aquifers, increasing the EC up to $10,000 \mu \mathrm{S} \mathrm{cm}^{-1}$ (Raeisi and Moor, 1993). The Salt Gachsaran Formation outcrops in the reservoir of a few dams, for example Kowsar and Maroon, but the quality of water is not affected because no salt outcrops in the reservoir and the strike is parallel to the dam axis, so that the marly units prevent flow toward the reservoir.

\section{Conclusions}

The main gypsum formations in Iran are the Upper Red, Gachsaran, Sachun, and Hith Anhydrite, making up five percent of Iran's total land area. The Upper Red, Sachun, and Hith Anhydrite Formations are predominantly composed of gypsum and marlstone. The Gachsaran Formation is divided into the SGF and NSGF. The NSGF consists of alternating units of anhydrite or gypsum, gypsiferous limestone, or dolomites. The SGF is composed of alternating units of gypsum, marl, and salt. The quality of springs emerging from the GF strongly reflects the lithology of the groundwater route. The main characteristics of the springs emerging from NSGF and SGF gypsum units without any hydraulic connection to salt units include mostly low discharge and sulfate water type, with electrical conductivity values of less than $3500 \mu \mathrm{S} \mathrm{cm} \mathrm{cm}^{-1}$. Chloride type water and a wide range of ECs, up to halite saturation, are characteristics of those SGF springs with direct connection between the gypsum and salt units.

The Tangsorkh (NSGF) and Ambal and Salbiz (SGF) sites were selected to study the detailed hydrogeology of the GF. The salt units of GF are not exposed in Iran due to the high salt dissolution rate, except at the Ambal site and another small region where salt ascends continuously by tectonic pressures. In the GF, the marly layers usually hydraulically disconnect the narrow gypsum beds from unexposed halite, resulting in very low discharge from springs and dominantly diffuse flow, preventing cave and sinkhole development and causing the general flow to be parallel to the bedding plane. Recharge water in the unexposed salt units flows deep, dissolving the deep halite units, converging towards the river bed, and ultimately emerging as saline or brine springs. Some special hydrogeological settings, for example, a tectonically active zone or where there is inflow from an adjacent river, result in the development of a conduit system, formation of collapse sinkholes in the halite and gypsum units, and consequent connection of the gypsum and halite units. In such a case, the general flow direction may not be in the direction of the bedding planes, and it will depend on other parameters of karst development, such as a highly soluble lithology or the local base level. Gachsaran Formation water with an EC of less than $7000 \mu \mathrm{S} \mathrm{cm}^{-1}$ is used for irrigation. The lowdischarge saline and brine GF spring waters are usually diluted to acceptable levels by mixing with the good quality waters of permanent rivers, but in several cases, the salty water in the GF degrades the quality of nearby karstic and alluvium aquifers.

\section{ACKNOWLEDGEMENTS}

This research was supported financially by Shiraz University. The authors would like to thank Mr. Arash Nadri and his colleagues from the Khuzestan Regional Water Authority and Mr. Siavash Behruz from the Karst Research Centre of Iran for providing useful information.

\section{REFERENCES}

Aghanabati, A., 2006, Geology of Iran: Ministry of Industry and Mines, Geological Survey of Iran, (in Farsi) $576 \mathrm{p}$.

Aghdam, J., 2012, Hydrogeology of gypsum formations in the south of Iran [Ph.D. thesis]: Shiraz, University of Shiraz, 120 p.

Aghdam, J.A., Zare, M., Capaccioni, B., Raeisi, E., and Forti, P., 2012, The Karun River waters in the Ambal ridge region (Zagros mountain Range, southwestern Iran): mixing calculation and hydrogeological implications: Carbonates and Evaporites (in press). doi:10.1007/ s13146-012-0083-8.

Ashjari, J., and Raeisi, E., 2006, Lithological control on water chemistry in karst aquifers of the Zagros Range, Iran: Cave and Karst Science, v. 33 , no. 3 , p. 111-118.

Bagheri, R., 2007, Leakage potential in Seymareh dam site [M.Sc. thesis]: Shiraz, University of Shiraz, (in Farsi) 225 p.

Bahadori, A., Carranza, E.J.M., and Soleimani, B., 2011, Geochemical analysis of evaporite sedimentation in the Gachsaran Formation, Zeloi oil field, southwest Iran: Journal of Geochemical Exploration, v. 111, p. 97-112. doi:10.1016/j.gexplo.2011.02.007.

Bahroudi, A., and Koyi, H.A., 2004, Tectono-sedimentary framework of the Gachsaran Formation in the Zagros foreland basin: Marine and Petroleum Geology, v. 21, p. 1295-1310. doi:10.1016/j.marpetgeo. 2004.09.001.

Berberian, M., and King, G.C.P., 1981, Towards a paleogeography and tectonic evolution of Iran: Canadian Journal of Earth Sciences, v. 18, p. 210-265. doi:10.1139/e81-019.

Darvishzadeh, A., 2003, Geology of Iran, Tehran, Amir Kabir, 901 p.

Dunnington, H.V., 1968, Salt-tectonic features of Northern Iraq, in Mattox, R.B., ed., Saline Deposits: A Symposium Based on Papers from the International Conference on Saline Deposits, Geological Society of America Special Paper 88, p. 183-227.

Edgell, H.S., 1996, Salt tectonics in the Persian Gulf basin, in Alsop, G.L., Blundell, D.L., and Davison, I., eds., Salt Tectonics, Geology Society of London, Special Publication 100, p. 129-151. doi:10.1144/ GSL.SP.1996.100.01.10

Ford, D.C., 1997, Principal features of evaporite karst in Canada: Carbonates and Evaporites, v. 12, no. 1, p. 15-23. doi:10.1007/BF03175798. 
Ford, D.C., and Williams, P.W., 1989, Karst Geomorphology and Hydrology, London, Unwin Hyman, 601 p.

Gill, W.D., and Ala, M.A., 1972, Sedimentology of Gachsaran Formation (lower Fars series), Southwest Iran, American Association of Petroleum Geologists Bulletin 56, p. 1965-1974.

Gutiérrez, F., Calaforra, J.M., Cardona, F., Orti, F., Durán, J.J., and Garay, P., 2008, Geological and environmental implications of the evaporate karst in Spain: Environmental Geology, v. 53, p. 951-965. doi:10.1007/s00254-007-0721-y.

Hessami, K., Koyi, H.A., Talbot, C.J., Tabasi, H., and Shabanian, E., 2001, Progressive unconformities within an evolving foreland foldthrust belt, Zagros Mountains: Journal of the Geological Society, v. 158, p. 969-981. doi:10.1144/0016-764901-007.

James, G.A., and Wynd, J.D., 1965, Stratigraphic nomenclature of Iranian Oil Consortium Agreement Area: American Association of Petroleum Geologists Bulletin, v. 49, no. 12, p. 2182-2245.

Johnson, K.S., 1996, Gypsum karst in the United States: International Journal of Speleology, v. 25, no. 3-4, p. 183-193.

Johnson, K.S., 2003, Evaporite-karst problems in the United States, in Johnson, K.S., and Neal, J.T., eds., Evaporite Karst and Engineering/ Environmental Problems in the United States, Oklahoma Geological Survey, Circular 109, p. 1-20.

Kashfi, M.S., 1980, Stratigraphy and environmental sedimentology of lower Fars Group (Miocene), South-Southwest Iran: American Association of Petroleum Geologists Bulletin, v. 64, p. 2095-2107. doi:10.1306/2F919742-16CE-11D7-8645000102C1865D.

Khosro Tehrani, K., 1987, Stratigraphy and formations type sections, Tehran, University of Tehran, (in Farsi) 260 p.

Klimchouk, A., and Andrejchuk, V., 1996, Environmental problems in gypsum karst terrains: International Journal of Speleology, v. 25, no. 3-4, p. 145-156.

Klimchouk, A., Forti, P., and Cooper, A., 1996, Gypsum karst of the World: a brief overview: International Journal of Speleology, v. 25, no. $3-4$, p. $159-181$.

Mahab Ghodss Consulting Engineers, 2009, Slope Stability Analysis of the Reservoir, Upper Gotvand Dam, Iran Water \& Power Resources Development Company, 48 p.
Maximovitch, G.A., 1962, Karst of gypsum and anhydrite of the globe (geotectonical relations, distribution, and major peculiarities), in Obshchiye voprosi karstovedemiya: Moscow, p. 108-113 (in Russian).

Mostofi, B., and Frei, E., 1959, The main sedimentary basins of Iran and their oil possibilities, Proceedings, $5^{\text {th }}$ World Petroleum Congress, New York, section 1, paper 17, $10 \mathrm{p}$.

Motiei, H., 1993, Treatise on the geology of Iran - stratigraphy of Zagros: Editor-in-Chief, A. Hushmandzadeh. Tehran, Geological Survey of Iran, (in Farsi) $536 \mathrm{p}$.

Murris, R.J., 1980, Middle East, stratigraphic evolution and oil habitat: American Association of Petroleum Geologists Bulletin, v. 64, p. $597-618$.

O'Brien, C.A.E., 1957, Salt diapirism in South Persia: Geologie en Mijnbouw, v. 19 , p. 357-376.

Oveisi, B., 2001, Resume of Kelestan geological map report, scale 1:100000, Geological Survey \& Mineral Exploration of Iran, sheet No. 6449.

Raeisi, E., and Moore, F., 1993, The effect of evaporitic formations on the quality of karst water: Iranian Journal of Science \& Technology, v. 17 , no. 2 , p. $91-103$.

Rahimi, M., 2006, Effect of rainfall, temperature, geological factors, and level base of erosion on characteristics of Asmari-Jahrum Formations in south-central Iran [M.Sc. thesis]: Shiraz, University of Shiraz, (in Farsi) 163 p.

Stöcklin, J., 1968, Salt deposits of the Middle East, in Mattox, R.B., ed., Saline Deposits: A Symposium Based on Papers from the International Conference on Saline Deposits, Geology Society of America, Special Paper 88, p. 157-181.

Stöcklin, J., and Setudehnia, A., 1977, Stratigraphic Lexicon of Iran, Ministry of Industry and Mines, Geological Survey of Iran, Report No. 18-1971, Second Edition, 370 p.

Talbot, C.J., and Alavi, M., 1996, The past of a future syntaxis across the Zagros, in Alsop, G.I., Blundell, D.J., and Davison, I., eds., Salt Tectonics. Geological Society of London Special Publication 100, p. 89-109. doi:10.1144/ GSL.SP.1996.100.01.08. 